\title{
Acclimatization Strategy of Chlamydomonas sp. BTA 4152 for Growing in Natural Rubber Latex Processing Wastewater
}

\author{
Swapan Kumar Sinha' ${ }^{1}$, Arghyadeep Gupta ${ }^{2}$ \\ ${ }^{1}$ TERI-Northeastern Regional Centre, Express Highway, Chachal, Guwahati-781036, Assam, India, \\ ${ }^{2}$ TERI-Northeastern Regional Centre, Express Highway, Chachal, Guwahati-781036, Assam, India,
}

\begin{abstract}
Algal biomass a potential renewable feedstock for 3rd generation biofuel only if the production costs are substantially reduced avoiding added stress on water resources. The waste water generated from various sources has substantial amounts of nutrients load are useful for algae growing. Selection of proper waste water and its ready access in large volume round the year remain a big concern. While wastewater as such cannot be used for algal culture it needed dilution to right concentration and robust algal strains either screened or acclimatized. This research finding reports the three steps of acclimatization process of Chlamydomonas sp. BTA 4152 for growing in rubber wastewater $(\mathrm{RW})$. In the first step $13.3 \times 10^{4}$ cells/ml of cells were grown in $20,40,60,80,100 \% \mathrm{RW}$ recorded highest growth $\left(83.1 \times 10^{4}\right.$ cells $\left./ \mathrm{ml}\right)$ with net increase of 5.2 folds in $20 \% \mathrm{RW}$ after 2 weeks. The same cells cultured in $20,40,60,80$ and $100 \% \mathrm{RW}$ showed highest growth $\left(1024 \times 10^{4}\right.$ cells $\left./ \mathrm{ml}\right)$ with net increase of 2.22 fold in $40 \% \mathrm{RW}$ in 2 weeks. Finally the acclimatized cells in $40 \% \mathrm{RW}$ cultured in $40,60,80$ and $100 \% \mathrm{RW}$ highest growth $\left(1450 \times 10^{4} \mathrm{cells} / \mathrm{ml}\right)$ with net increase of 39.28 folds and 504mg/l dry biomass in 5 weeks.
\end{abstract}

Keywords: Chlamydomonas sp. BTA 4152, rubber wastewater, acclimatization, biomass

\section{Introduction}

Third-generation biofuels refers to non-arable crops as precursor with easier extraction process such as algae. Algae biomass is considered as viable energy feedstock is devoid of the major drawbacks associated with first and second generation biofuels $[1,2]$. Nutrients and carbon are the essential and expensive input for microalgal growth therefore wastewater is explored as a cheap alternative to expensive synthetic growth media for large-scale microalgal cultivation [3]. Chlamydomonas reinhardtii is grown in municipal wastewater as a feedstock for biofuel production and also remove about $80 \%$ of nitrate and $15 \%$ of phosphate [4]. Algal can be grown on marginal land using wastewater, can be harvested repeatedly and many species contain high lipid content which is essential for biodiesel production [3, 5].

India's rubber plantation sector is dominated by small holdings that accounts for $92 \%$ of the production and $89 \%$ of the area. Since 1986, Rubber Board a statutory body constituted by Government of India promote formation of voluntary associations of small growers called the Rubber Producers' Societies (RPS) for facilitating extension communication, and to adopt suitable measures to increase the production and productivity of small and marginal holdings. Presently there are over 2500 RPSs across India, representing more than a million farmers, cultivating over seven lakh hectares of which the average holding is 0.54 ha. The most of the RPSs are registered in Kerala and nearly 250 of them are registered in the North East region. Each RPS has a Rubber Processing Centre (RPC) for group processing of latex collected from surrounding farmers where Ribbed Smoked Sheet (RSS) are produced. The RPC consume large volume of water and chemical for processing of rubber. The effluent of RPC contains wash water, small amounts of uncoagulated latex and serum with small quantities of protein, carbohydrates, lipids, carotenoids and salts [6], contain strong colour, a large amount of suspended solids, a highly fluctuating $\mathrm{pH}, \mathrm{COD}, \mathrm{BOD}$, etc. [7,8]. Because of these characteristics, treatment of rubber wastewater is an essential requirement before its disposal to natural water system [9, 10, 11]. During 2008-09, out of 6.61 lakh ha area covered under rubber plantation in India latex are tapped in 4.63 lakh ha area producing 8.645 lakh MT of dry natural rubber@an average yield of 1.867 MT per hectare land. Rubber processing industry usually generates large quantities of wastewater containing high concentration of organic matter, suspended solids and nitrogen [12]. Processing of a kilogram of dry rubber requires $15-20 \mathrm{~L}$ of water thus India generated about $12.96-17.29$ billion liters of wastewater from processing of 8.645 lakh MT dry natural rubbers during 2008-09. Rubber plantation and subsequent processing for natural rubber in the northeast India has been considered as rehabilitation package due economic viability at the farmer's perspective and is slated for expansion for 4.5 lakh ha area from existing 0.88 lakh ha. Likewise the group processing of latex for RSS rubber in RPC is set to increase many fold in years to come leading to severe stress of water resources. Besides stress of water resources the waste water discharge of these RPC contains high load of nutrient nitrogen and phosphorous besides other may cause serious threat to environment endangering millions of livelihood associated. The high level of phosphate and ammonia in rubber effluent makes it a good medium for algal growth and can result in eutrophication of surface waters if discharged without proper treatment [11]. The published report on rubber wastewater focuses on its bioremediation and none of the research has directed for use of rubber waste water as resource. Therefore present experiment has been attempted to optimize the

\section{Volume 4 Issue 2, February 2015 www.ijsr.net}




\section{International Journal of Science and Research (IJSR) \\ ISSN (Online): 2319-7064}

Index Copernicus Value (2013): 6.14 | Impact Factor (2013): 4.438

acclimatization process for utilization of the rubber wastewater in algae cultivation.

\section{Materials and Methods}

\section{A. Materials}

Rubber wastewater (RW) used in the study was collected from Jalabasa Rubber Producers Society, Jalabasa, North Tripura district, Tripura , India. Chlamydomonas sp. BTA 4152 strain used in this work was isolated from natural stream at Dhupdhara, Goalpara district, Assam, India (Latitude $25^{\circ} 57^{\prime} 11.6$ : Longitude $91^{\circ} 04^{\prime} 31.2$ ) and deposited to Fresh water algal Repository, Institute of Bioresources and Sustainable Development, Government of India.

\section{B. Inoculum Preparation and Experiments}

Seed culture was prepared by inoculating Chlamydomonas sp. BTA 4152 into BG11 media and it was grown till it reached early logarithmic phase (6-7 days). The seed culture thus prepared was then inoculated in $150 \mathrm{ml}$ Erlenmeyer flask containing $50 \mathrm{ml}$ culture medium with inoculum size of $10 \%(\mathrm{v} / \mathrm{v})$. Algal strain was grown at $28 \pm 2{ }^{\circ} \mathrm{C}$ and at $\mathrm{pH} 6.8$ 7 under 14:10 light-dark cycle with light intensity of 2000 lx. During incubation, the cultures were periodically gently mixed to ensure homogeneous mixing, release of $\mathrm{O} 2$, and to avoid settling and sticking of algae on to the flask wall. The stationary phase algal cells were inoculated for acclimatization experiment hereafter (table1).

Table 1: Three stage acclimatization strategies for Chlamydomonas sp. BTA 4152 in rubber wastewater

\begin{tabular}{|c|c|c|c|c|c|c|c|}
\hline $\begin{array}{c}\text { Acclimatization } \\
\text { stage }\end{array}$ & Inoculum source & \multicolumn{6}{|c|}{ Rubber wastewater concentration in } \\
\hline 1 & Fresh & 0 & 20 & 40 & 60 & 80 & 100 \\
\hline 2 & $\begin{array}{c}\text { Acclimatized in } \\
20 \% \text { RW }\end{array}$ & 20 & 40 & 60 & 80 & 100 \\
\hline 3 & $\begin{array}{c}\text { Acclimatized in } \\
40 \% \mathrm{RW}\end{array}$ & & 40 & 60 & 80 & 100 \\
\hline
\end{tabular}

\section{Acclimatisation stage I. Cultivation of} Chlamydomonas sp. BTA 4152 in Rubber wastewater without any supplementation:

RW used as raw without any interference except dilution with tap water. RW was diluted with tap water to produce dilution percentages of $20,40,60,80$, and 100. In another set of experiment RW was enriched with BG11 medium and $\mathrm{pH}$ was adjusted for only for control (BG11 media). The experiment was set in $500 \mathrm{ml}$ Erlenmeyer conical flasks and replicated three times. The stock solution of Chlamydomonas $s p$. BTA 4152 was maintained at $28{ }^{\circ} \mathrm{C} \pm 1$ with photoperiod of $12 \mathrm{hrs}$ light/dark period provided by fluorescent lamps at the light intensity of 2000lux. Experiment was initiated with inoculation of $10 \% \mathrm{v} / \mathrm{v}$ inoculum density $13-18 \times 10^{4}$ cells $/ \mathrm{ml}$ of Chlamydomonas sp. BTA 4152 stock culture. The experiment run for 14 days at temperature $28^{\circ} \mathrm{C} \pm 2$, and photoperiod of 14/10 light /dark with light intensity 2000 by fluorescent tubes (Havels) orbital shaker (Thermo Fisher make)

D. Acclimatisation stage II. Cultivation of Chlamydomonas sp. BTA 4152 in Supplemented Rubber wastewater:

In the second experiment, Chlamydomonas sp. BTA 4152 acclimatized in $20 \% \mathrm{RW}$ was used as inoculums and subcultured in supplemented RW at 20, 40, 60, 80 and $100 \%$ in tap water. All the culture conditions were kept same as in experiment I.

E. Acclimatisation stage III. Cultivation of Chlamydomonas sp. BTA 4152 in Supplemented Rubber wastewater:

In the third experiment, Chlamydomonas sp. BTA 4152 acclimatized in $40 \%$ RW was as inoculum and subcultured in supplemented RW at 40, 60, 80 and $100 \%$ in tap water. All the culture conditions were kept same as in experiment I. none of culture medium for acclimatization was adjusted for $\mathrm{pH}$.

\section{F. Growth Evaluation:}

Growth was measured in terms of dry biomass and cell count. At the different interval of experiment cells were counted using a Haemocytometer (Neubauer).

Net growth fold $=\mathrm{C} 1-\mathrm{C} 0 / \mathrm{C} 0$

Where $\mathrm{C} 0$ is the initial cell count, $\mathrm{C} 1$ is the subsequent cell count after incubation.

For dry weight method, the algal cultures were pelletized by centrifugation at $7500 \mathrm{rpm}$ (Eppendorf, 5810R) for 15 minutes. Cells were washed with glass-distilled water, again centrifuged and dried in an oven (Thermo Fisher) at $105{ }^{\circ} \mathrm{C}$ for 24 hours or until constant weight. Simultaneously $\mathrm{pH}$ of the culture media was recorded using $\mathrm{pH}$ meter (SenTix ${ }^{\circledR} 81$, Merck). The net growth fold was calculated based on following equation

\section{Result}

Rubber wastewater discharge from processing facility was opaque in colour, malodour due to ammonia and $\mathrm{H}_{2} \mathrm{~S}$ and recorded $\mathrm{pH} 3.5$. This discharge is usually treated in floating dome anaerobic digester for biogas production, however due to non replenishment of proper $\mathrm{C} / \mathrm{N}$ ratio the anaerobic digester remain non operation for the 50 processing facilities visited.

\section{1) First Acclimatization}

Growth performance for Chlamydomonas sp. BTA 4152 species in various concentration of Rubber wastewater (20, 40, 60, 80 and $100 \% \mathrm{v} / \mathrm{v}$ ) without adjusting $\mathrm{pH}$ for 2 weeks of incubation is illustrated in table 2,3,4 and Fig 1. 


\section{International Journal of Science and Research (IJSR) \\ ISSN (Online): 2319-7064}

Index Copernicus Value (2013): 6.14 | Impact Factor (2013): 4.438

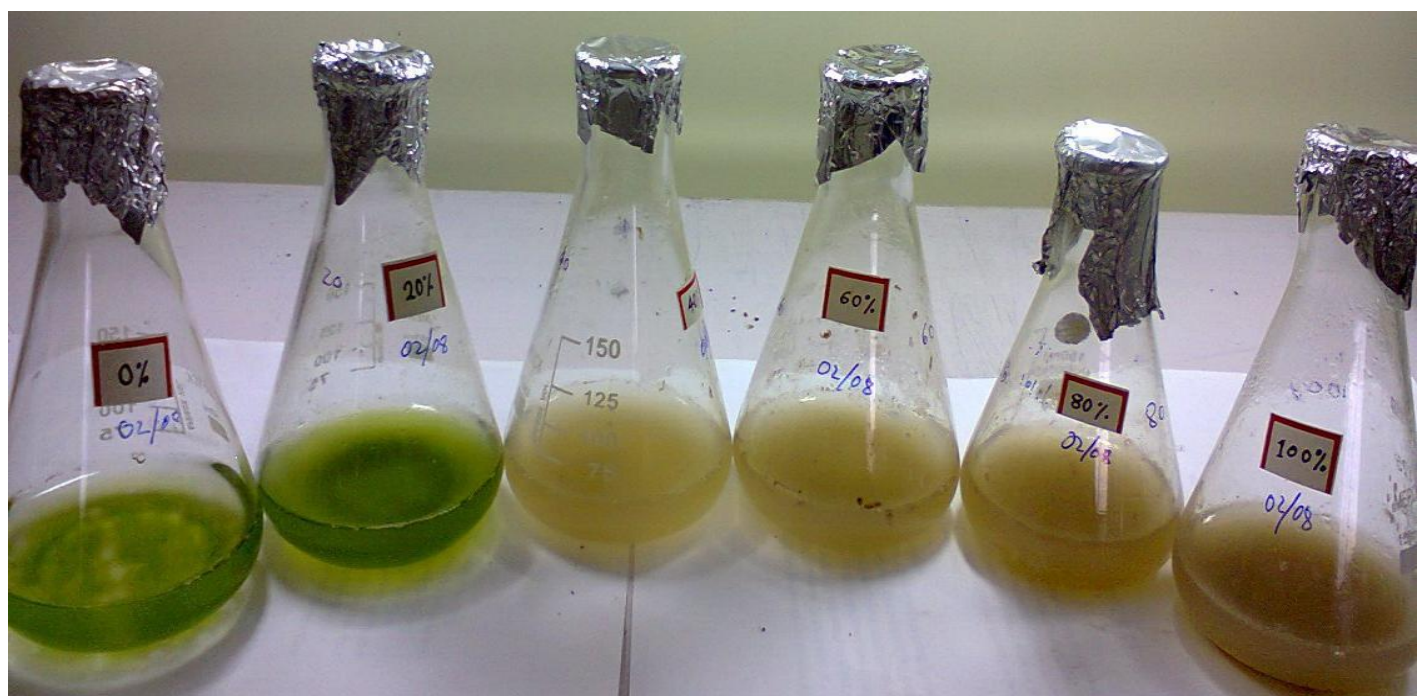

Figure 1: Acclimatization stage I of Chlamydomonas sp. BTA 4152 in Rubber wastewater (optimum growth in 20\%RW)

The highest growth $83.1 \times 10^{4}$ cells/ml and net 5.248 fold increase was recorded in $20 \% \mathrm{RW}$ where $\mathrm{pH}$ rose from 6 to 9. The enrichment of BG11 media with various concentration of RW (20,40, 60, 80 and 100\%) recorded no advantages over tap water (table 5, 6, 7). A similar finding was reported for Chlorella vulgaris growth of textile wastewater supplementation of with nutrients of BBM [13]. This could be attributed to super salinity situation in rubber wastewater due to enrichment of BG11.

Table 2: Growth performance of Chlamydomonas sp. BTA 4152 in tap water supplemented with rubber wastewater

\begin{tabular}{|c|c|c|c|c|c|c|}
\hline Tap water+ & \multicolumn{5}{|c|}{ Cell count $\left(\mathrm{x} 10^{4} / \mathrm{ml}\right)$ after days } \\
\cline { 2 - 7 } RW \% & 0 & 1 & 4 & 7 & 10 & 14 \\
\hline $0 \%$ & 13 & 19 & 27.4 & 40.3 & 51.3 & 54 \\
\hline $20 \%$ & 13.3 & 26 & 35 & 46.8 & 63 & 83.1 \\
\hline $40 \%$ & 18.5 & 19.1 & 18.8 & 19.3 & 20.1 & 38.4 \\
\hline $60 \%$ & 16.2 & 20 & 19.8 & 21.4 & 20.8 & 22.3 \\
\hline $80 \%$ & 17.7 & 20.3 & 20.9 & 21.5 & 20.68 & 20.5 \\
\hline $100 \%$ & 14.6 & 20.5 & 20.4 & 24.4 & 20.83 & 21.9 \\
\hline
\end{tabular}

Table 3: Net growth fold of Chlamydomonas sp. BTA 4152 in tap water supplemented with rubber wastewater

\begin{tabular}{|l|l|l|l|l|l|l|}
\hline $\begin{array}{c}\text { Tap water } \\
\text { RW \% }\end{array}$ & $\begin{array}{c}\text { Starting } \\
\text { cell count }\end{array}$ & \multicolumn{5}{|c|}{$\begin{array}{c}\text { Fold increase in Cell count (x } \\
\left.10^{4} / \mathrm{ml}\right) \text { after days }\end{array}$} \\
\cline { 2 - 7 } & 0 & 1 & 4 & 7 & 10 & 14 \\
\hline $0 \%$ & 13 & 0.46 & 1.11 & 2.10 & 2.95 & 3.15 \\
\hline $\mathbf{2 0 \%}$ & 13.3 & 0.96 & 1.63 & 2.52 & 3.74 & 5.25 \\
\hline $40 \%$ & 18.5 & 0.03 & 0.02 & 0.04 & 0.09 & 1.08 \\
\hline $60 \%$ & 16.2 & 0.24 & 0.22 & 0.32 & 0.29 & 0.38 \\
\hline $80 \%$ & 17.7 & 0.15 & 0.18 & 0.22 & 0.17 & 0.16 \\
\hline $100 \%$ & 14.6 & 0.40 & 0.40 & 0.67 & 0.43 & 0.50 \\
\hline
\end{tabular}

Table 4: changes of $\mathrm{pH}$ in Chlamydomonas sp. BTA 4152 grown in tap water supplemented with rubber wastewater

\begin{tabular}{|c|c|c|c|c|c|c|}
\hline Tap water + RW & \multicolumn{6}{|c|}{$\mathrm{pH}$ values after days } \\
\cline { 2 - 7 }$\%$ & 0 & 1 & 4 & 7 & 10 & 14 \\
\hline $0 \%$ & 6 & 6.2 & 6.6 & 7 & 7.8 & 8 \\
\hline $20 \%$ & 6 & 6.3 & 7 & 7.3 & 8 & 9 \\
\hline $40 \%$ & 5 & 6.2 & 6.3 & 6.5 & 7 & 7.5 \\
\hline $60 \%$ & 4.5 & 6 & 6.2 & 6 & 7 & 7 \\
\hline $80 \%$ & 4 & 6 & 6.5 & 6.5 & 7 & 6.5 \\
\hline $100 \%$ & 3.5 & 5.5 & 6.4 & 6.5 & 7.1 & 7.5 \\
\hline
\end{tabular}

Table 5: Growth performance of Chlamydomonas sp. BTA 4152 in BG11supplemented with rubber wastewater

\begin{tabular}{|c|c|c|c|c|c|c|}
\hline BG11+ & \multicolumn{7}{|c|}{ Cell count $\left(\mathrm{x} 10^{4} / \mathrm{ml}\right)$ after days } \\
\cline { 2 - 7 } RW \% & 0 & 1 & 4 & 7 & 10 & 14 \\
\hline $0 \%$ & 17 & 21.9 & 32.1 & 41.2 & 47 & $\mathbf{7 0}$ \\
\hline $20 \%$ & 16.94 & 18.8 & 24 & 35 & 40.6 & 40 \\
\hline $40 \%$ & 24.4 & 19.4 & 19.1 & 22.2 & 24 & 18.3 \\
\hline $60 \%$ & 23.5 & 20 & 20.4 & 21 & 24.6 & 20.6 \\
\hline $80 \%$ & 19.1 & 20.17 & 23.3 & 24.5 & 29 & 22.7 \\
\hline $100 \%$ & 21 & 20.2 & 24 & 23 & 27.3 & 22 \\
\hline
\end{tabular}

Table 6: Net growth fold of Chlamydomonas sp. BTA 4152 in BG11supplemented with rubber wastewater

\begin{tabular}{|l|l|l|l|l|l|l|}
\hline \multirow{2}{*}{$\begin{array}{c}\text { BG11 } \\
\text { RW }\end{array}$} & $\begin{array}{c}\text { Starting } \\
\text { cell count }\end{array}$ & \multicolumn{5}{|c|}{ Fold increase in Cell count $\left(\mathrm{x} 10^{4} / \mathrm{ml}\right)$} \\
\cline { 2 - 7 } & 0 & 1 & 4 & 7 & 10 & 14 \\
\hline $0 \%$ & 17 & 0.29 & 0.89 & 1.42 & 1.77 & 3.12 \\
\hline $\mathbf{2 0 \%}$ & 16.94 & 0.11 & 0.42 & 1.07 & 1.40 & 1.36 \\
\hline $40 \%$ & 24.4 & -0.21 & -0.22 & -0.09 & -0.02 & -0.25 \\
\hline $60 \%$ & 23.5 & -0.15 & -0.13 & -0.11 & 0.05 & -0.12 \\
\hline $80 \%$ & 19.1 & 0.06 & 0.22 & 0.28 & 0.52 & 0.19 \\
\hline $100 \%$ & 21 & -0.04 & 0.14 & 0.10 & 0.30 & 0.05 \\
\hline
\end{tabular}

Table 7: Changes in pH for Chlamydomonas sp. BTA 4152 grown in tap water supplemented with rubber wastewater

\begin{tabular}{|c|c|c|c|c|c|c|}
\hline BG11+ & \multicolumn{7}{|c|}{$\mathrm{pH}$ values after days } \\
\cline { 2 - 7 } RW \% & 0 & 1 & 4 & 7 & 10 & 14 \\
\hline $0 \%$ & 7 & 7.2 & 9 & 6.5 & 7.6 & 8 \\
\hline $20 \%$ & 6 & 6.3 & 7.6 & 7 & 7.3 & 7 \\
\hline $40 \%$ & 5.5 & 6.6 & 6.5 & 7 & 7.1 & 6 \\
\hline $60 \%$ & 5 & 6.9 & 7 & 6.5 & 6.7 & 6.5 \\
\hline $80 \%$ & 4.5 & 6.8 & 7.4 & 7 & 7.2 & 6.5 \\
\hline $100 \%$ & 4 & 6.8 & 7.4 & 7.5 & 7.5 & 6.5 \\
\hline
\end{tabular}

\section{1) Second Acclimatization}

The two weeks old Chlamydomonas sp. BTA 4152 culture in $20 \%$ waste water when inoculated in 20,40,60,80,100\% RW the highest growth recorded $\left(1024 \times 10^{4}\right.$ cells $\left./ \mathrm{ml}\right)$ with calculated net increase of 2.22 fold in 2 weeks culture in $40 \%$ RW followed by $60 \%$ RW with $932 \times 10^{4}$ cells $/ \mathrm{ml}$ and 1.8 fold increase (table 8,9). The $\mathrm{pH}$ rose from 5 to $>8$ in all the concentration of waste water (table 10).

\section{Volume 4 Issue 2, February 2015 www.ijsr.net}




\section{International Journal of Science and Research (IJSR) \\ ISSN (Online): 2319-7064 \\ Index Copernicus Value (2013): 6.14 | Impact Factor (2013): 4.438}

Table 8: Growth performance of Chlamydomonas sp. BTA 4152 acclimatized in $20 \%$ RW cultured in tap water supplemented with rubber wastewater

\begin{tabular}{|c|c|c|c|c|c|c|c|}
\hline Tap water + & \multicolumn{7}{|c|}{ Cell count $\left(\mathrm{x} 10^{4} / \mathrm{ml}\right)$ after days } \\
\cline { 2 - 8 } RW \% & 0 & 2 & 4 & 7 & 9 & 11 & 14 \\
\hline $20 \%$ & 304 & 288 & 144 & 464 & 464 & 396 & 356 \\
\hline $40 \%$ & 312 & 368 & 192 & 320 & 320 & 520 & 1024 \\
\hline $60 \%$ & 324 & 336 & 320 & 400 & 400 & 408 & 932 \\
\hline $80 \%$ & 304 & 256 & 256 & 320 & 320 & 476 & 408 \\
\hline $100 \%$ & 324 & 356 & 176 & 400 & 400 & 492 & 384 \\
\hline
\end{tabular}

Table 9: Net growth fold of Chlamydomonas sp. BTA 4152 acclimatized in $20 \%$ RW cultured in tap water supplemented with rubber wastewater

\begin{tabular}{|c|c|c|c|c|c|c|c|}
\hline RW \% & $\begin{array}{c}\text { Starting } \\
\text { cell count }\end{array}$ & \multicolumn{6}{|l|}{ Fold increase in Cell count (x $\left.10^{4} / \mathrm{ml}\right)$ after days } \\
\cline { 2 - 8 } & 0 & 2 & 4 & 7 & 9 & 11 & 14 \\
\hline $20 \%$ & 304 & -0.05 & -0.53 & 0.53 & 0.53 & 0.30 & 0.17 \\
\hline $40 \%$ & 312 & 0.18 & -0.39 & 0.03 & 0.03 & 0.67 & 2.28 \\
\hline $60 \%$ & 324 & 0.04 & -0.01 & 0.24 & 0.24 & 0.26 & 1.88 \\
\hline $80 \%$ & 304 & -0.16 & -0.16 & 0.05 & 0.05 & 0.57 & 0.34 \\
\hline $100 \%$ & 324 & 0.10 & -0.46 & 0.24 & 0.24 & 0.52 & 0.19 \\
\hline
\end{tabular}

Table 10: Changes in pH of Chlamydomonas $s p$. BTA 4152 acclimatized in $20 \%$ RW cultured in tap water supplemented with rubber wastewater

\begin{tabular}{|c|c|c|c|c|c|c|c|}
\hline Tap water + & \multicolumn{7}{|c|}{$\mathrm{pH}$ values after days } \\
\cline { 2 - 8 } RW \% & 0 & 2 & 4 & 7 & 9 & 11 & 14 \\
\hline $20 \%$ & 5.6 & 6.2 & 7.5 & 8.4 & 8.78 & 9.0 & 9.2 \\
\hline $40 \%$ & 5.6 & 5.8 & 8 & 8.29 & 8.61 & 8.8 & 8.84 \\
\hline $60 \%$ & 5.5 & 5.7 & 7 & 8.1 & 8.54 & 8.5 & 8.67 \\
\hline $80 \%$ & 5 & 5.65 & 7.5 & 7.9 & 8.49 & 8.4 & 8.57 \\
\hline $100 \%$ & 5 & 5.61 & 4.5 & 7.4 & 8.12 & 8.2 & 8.36 \\
\hline
\end{tabular}

\section{2) Third Acclimatization}

The Chlamydomonas sp. BTA 4152 acclimatized in $40 \%$ waste water subcultured in $40,60,80,100 \%$ concentration incubated for 5 weeks and growth performance illustrated in Fig. 2,3,4.5. The $40 \%$ concentration of RW showed the highest cell counts $124 \times 10^{4}$ cells $/ \mathrm{ml}, 240 \times 10^{4}$ cells $/ \mathrm{ml}, 260$ $\mathrm{x} 10^{4} \mathrm{cells} / \mathrm{ml}, 530 \times 10^{4} \mathrm{cell} \mathrm{s} / \mathrm{ml}$ and $1450 \times 10^{4} \mathrm{cells} / \mathrm{ml}$ with net increase of $2.44,5.67,6.22,13.72$ and 39.28 folds after $1^{\text {st }}, 2^{\text {nd }}, 3^{\text {rd }} \cdot 4^{\text {th }}$ and $5^{\text {th }}$ weeks of incubation respectively. In the same period the $\mathrm{pH}$ rose from 5 to $8.73,8.95,9.19,9.24$ and 10.2 after $1^{\text {st }}, 2^{\text {nd }}, 3^{\text {rd }} \cdot 4^{\text {th }}$ and $5^{\text {th }}$ weeks of incubation respectively.

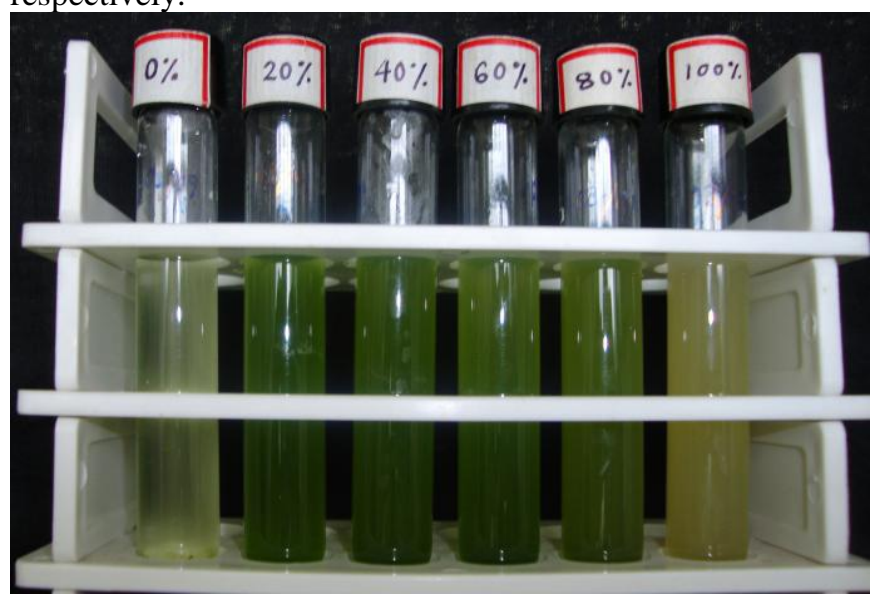

Figure 2: Acclimatization satge III of Chlamydomonas sp. BTA 4152 in Rubber wastewater (optimum growth in $40 \%$ RW
Fig.3Growth performance of Chlamydomonas sp. BTA 4152 acclimatized in $40 \% \mathrm{RW}$ cultured in tap water supplemented with rubber wastewater

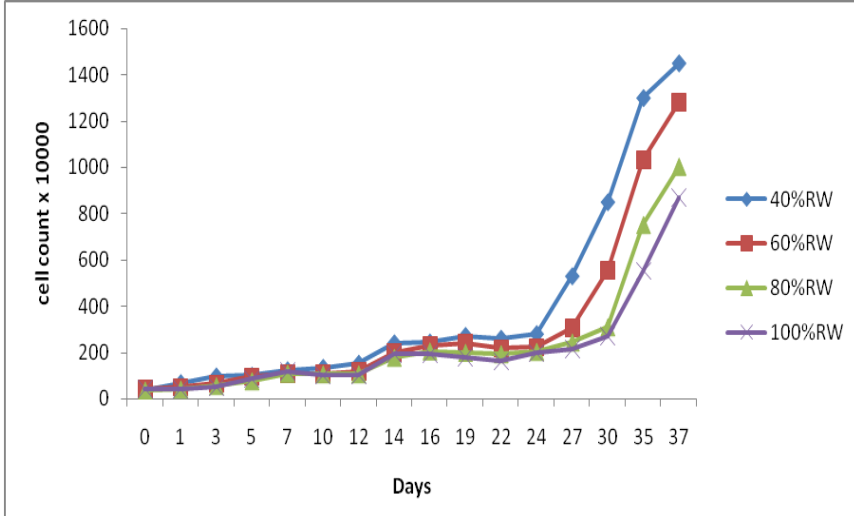

Figure 4: Net growth fold of Chlamydomonas sp. BTA 4152 acclimatized in $40 \%$ RW cultured in tap water supplemented with rubber wastewater

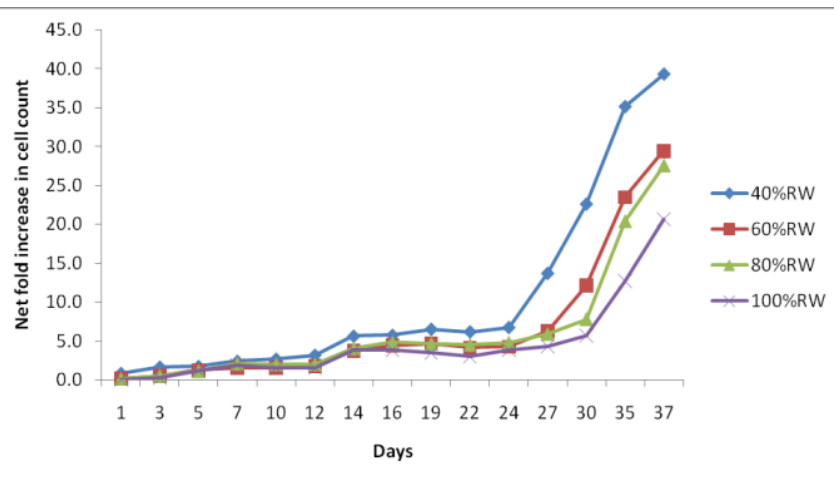

Figure 5: Changes in pH of Chlamydomonas sp. BTA 4152 acclimatized in $40 \%$ RW cultured in tap water supplemented with rubber wastewater

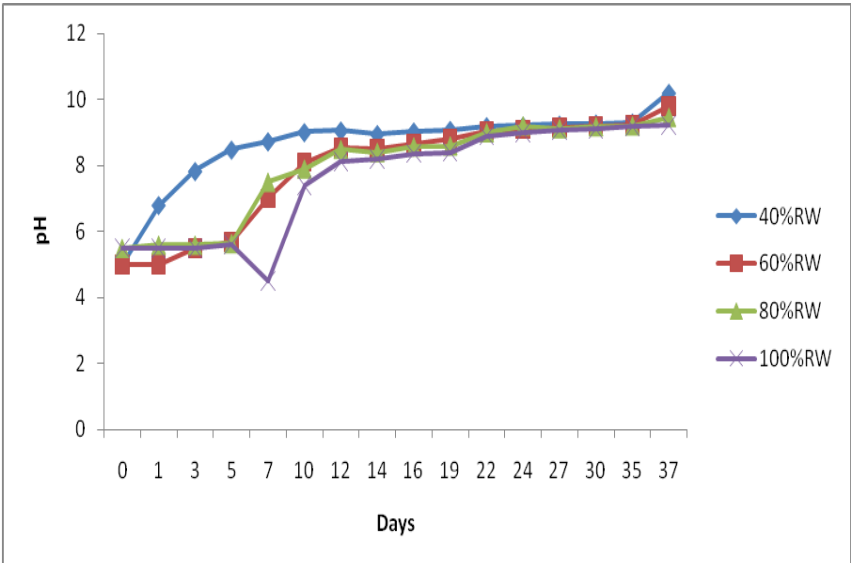

The highest biomass productivity (504 mg dry weight/l) of Chlamydomonas sp. BTA 4152 was recorded in $40 \%$ waste water (Fig.6) and productivity decreased with increasing RW concentration even after acclimatization.

Fig. 6 Biomass productivity of Chlamydomonas sp. BTA 4152 acclimatized in $40 \%$ RW cultured in tap water supplemented with rubber wastewater.

\section{Volume 4 Issue 2, February 2015 www.ijsr.net}




\section{International Journal of Science and Research (IJSR) \\ ISSN (Online): 2319-7064}

Index Copernicus Value (2013): 6.14 | Impact Factor (2013): 4.438

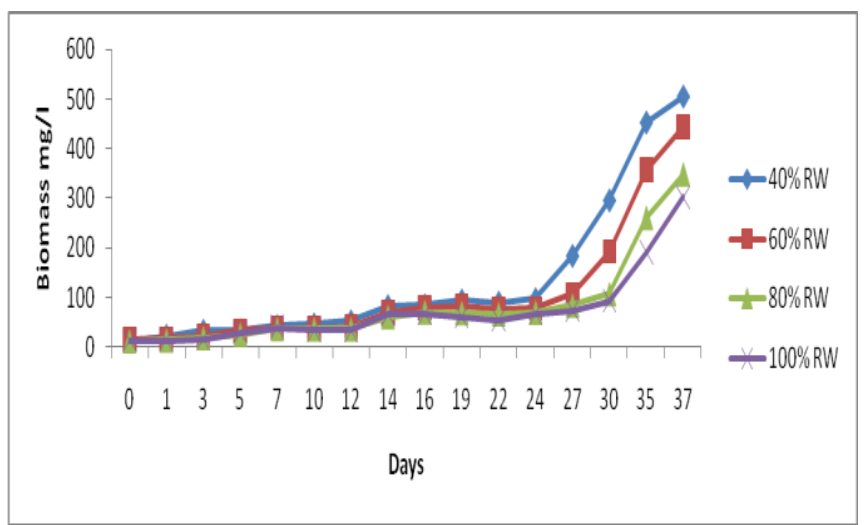

The raise in $\mathrm{pH}$ values is attributed to rapid photosynthesis by algae, which consume $\mathrm{CO} 2$ as a result, the carbonate and bicarbonate ions dissociate, as follows:

$2 \mathrm{HCO}_{3}{ }^{-} \rightarrow 3 \mathrm{CO}_{3}{ }^{2-}+\mathrm{H} 2 \mathrm{O}+\mathrm{CO} 2$

$\mathrm{CO}_{3}{ }^{2}+\mathrm{H} 2 \mathrm{O} 2 \leftrightarrow 2 \mathrm{OH}^{-}+\mathrm{CO} 2$

The resulting $\mathrm{CO} 2$ is fixed by the algae, and the hydroxyl ions accumulate thereby raising the $\mathrm{pH}$ to values above 10 .

Conventionally $\mathrm{NaOH}$ is used to neutralize acidic effluents and to reduce the cost of $\mathrm{NaOH}$, iron oxidation and limestone neutralization process are adopted because limestones are less expensive than lime [14]. The present findings indicates $\mathrm{pH}$ correction of rubber waste water in algal biomass production that would reduce cost and sludge significantly in environment friendly way besides generating raw materials for biofuel, fertilizer etc. Lee (2001) [15] reported tolerance of microalgae and utilization of nutrients from several domestic and industrial wastewaters. Both nitrogen and phosphorus present in wastewater discharge are the major source of eutrophication by algal bloom [16]. Screening and scrutiny of efficient algal species are necessary for assessing the biofuel prospects of algae. The native or indigenous algal species thriving in the wastewater conditions with at high $\mathrm{N}$ and $\mathrm{P}[17,18]$ concentration would be more beneficial than the commercially available strains which have a narrow range of tolerance. The locally isolated algae easily adapt to the wastewater conditions and are found to grow at higher biomass densities [17]. The Chlamydomonas sp. BTA 4152 used in the experiment isolated from fresh water also equally tolerate the wastewater toxicity and grow efficiently after the 3 stage acclimatization.

\section{3) Strategy flow chart ( 9 weeks)}

1. Inoculated Chlamydomonas sp. BTA 4152 in waste water at $0,20,40,60,80,100 \%$ strength in tap water without $\mathrm{pH}$ correction and incubated for 2 weeks

2. Selected the best concentration of waste water (20\%) with regard to cell count and $\mathrm{pH}$ change in the medium

3. Inoculated the Chlamydomonas sp. BTA 4152 strains from selected waste water concentration $(20 \%)$ to its higher strength of waste water $(20,40,60,80,100 \%)$ and incubated for another 2 weeks

4. Again selected the best concentration of waste water (40\%) with regard to cell count and raise in $\mathrm{pH}$ in the medium

5. Reinoculated the Chlamydomonas sp. BTA 4152 strains from $40 \%$ waste water concentration to its higher strength of wastewater $(40,60,80,100 \%)$ and incubated for another 5 weeks
6. The appropriately acclimatized Chlamydomonas sp. BTA 4152 strains ready for utilizing the wastewater as growing medium for production of biomass @ $500 \mathrm{mg} / 1$ after 5 weeks.

\section{Acknowledgement}

We are grateful to the Department of Biotechnology, Ministry of Science and Technology, Government of India for the sustained financial support and Dr. R K Pachauri, Director General, TERI for sustained motivation and infrastructure support.

\section{Reference}

[1] P.S. Nigam, A. Singh. Production of liquid biofuels from renewable resources. Progress in Energy and Combustion ScienceDOI: 10.1016/j.pecs.2010.01.003. 2010.

[2] Y. Chisti. Biodiesel from microalgae. Biotechnology Advances. 25, pp. 294-306. 2007.

[3] National Renewable Energy Laboratory. A Look Back at the U.S. Department of Energy's Aquatic Species Program: Biodiesel from Algae (Closeout Report). 1998

[4] Q.X. Kong, L. Li, B. Martinez, P. Chen, R. Ruan. Culture of microalgae Chlamydomonas reinhardtii in wastewater for biomass feedstock production. Appl. Biochem. Biotechnol. 160, pp 9-18. 2010

[5] V. Smith, B. Sturm, F. deNoyelles, S. Billings. The ecology of algal biodiesel production. Trends in Ecology and Evolution , 25 (5), pp 301-309. 2009.

[6] A. Abdul Rani. Environmental pollution in Malaysia: trends and prospects. Trends Anal. Chem. 14, pp. 191198. 1995.

[7] I.O. Asia, E.E. Akporhonor. Characterization and physicochemical treatment of wastewater from rubber processing factory. Int. J. Phys. Sci. 2, pp. 61-67. 2007.

[8] M. Mohammadi, H. Che Man, M.A. Hassan, P. Lai Yee. Treatment of wastewater from rubber industry in Malaysia. Afr. J. Biotechnol. 9, pp. 6233-6243. 2010.

[9] Atagana, H.I., Ejechi, B.O. and Ayilumo, A.M.. Fungi associated with degradation of wastes from rubber processing industry. Environ. Mon. Assess. 55, pp 401408. $1999 \mathrm{a}$

[10]H.I. Atagana, B.O. Ejechi, M.I. Ogodu. Bacteria associated with degradation of wastes from rubber processing industry. Environ. Mon. Assess. 59, pp. 145154. $1999 b$.

[11] M.A. Iyagba, A. Adoki, T.G. Sokari. Testing biological methods to treat rubber effluent. Afr. J. Agric. Res. 3, pp. 448-454. 2008.

[12]A. Rakkoed, S. Danteravanich, U. Puetpaiboon. Nitrogen removal in attached growth waste stabilization ponds of wastewater from a rubber factory. Water Sci. Technol. 40, pp. 45-52. 1999.

[13]Lima, Sing-Lai, Wan-Loy Chu, Siew-Moi Phang. Use of Chlorella vulgaris for bioremediation of textile wastewater. Bioresource Technology 101, pp. 73147322. 2010.

[14] J.P. Maree, M. de Beer, W.F. Strydom, A.D.M. Christie, F.B. Waanders. Neutralizing coal mine effluent with

\section{Volume 4 Issue 2, February 2015 www.ijsr.net}


limestone to decrease metals and sulphate concentrations. Mine Water Environ 23, pp. 81-6. 2004.

[15]Y. K. Lee. Microalgal mass culture systems and methods: Their limitation and potential. J Appl Phycol, 13, pp. 307-315. 2001.

[16] G. Shelef, W.J. Oswald, C.G. Golueke. The continuous culture of algae biomass on wastes. In Continuous Cultivation of Microorganisms, (Eds). I. Malek.1969

[17] D. M. Mahapatra, H. N. Chanakya, T.V. Ramachandra. $\mathrm{C}: \mathrm{N}$ ratio of sediments in a sewage fed urban lake. Int. J. Geo, 5, pp. 86-92. 2011.

[18] D.M. Mahapatra, B. N. Chanakya, T. V. Ramachandra. Treatment efficacy of algae based sewage treatment plants. Environ. Mon. Assess., 1-20; doi: 10.1007/s10661-013-3090-x. 2013.

\section{Author Profile}

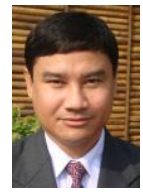

Swapan Kumar Sinha received the Ph.D degree in Biotechnology from Gauhati University in 2000. During 1996-2000, he stayed in State Forest Research Institute, Itanagar Arunachal, India for improvement of orchids. During 2000-2002 he stayed in Manipur University, Imphal, India for antioxidant properties screening of medicinal Zingiberales. Since 2002 he is in TERI, Guwahati, India involved in micropropagation, algal biofuel using wastewater.

Arghyadeep Gupta received the M.Sc. degree in Biotechnology from Bangalore University, India in 2002. Since 2009 he is working as Research Associate in TERI, Guwahati, India involved in algal biofuel using wastewater. 